\title{
ORANG CINA DAN PENGLIBATAN DALAM POLITIK DI NEGERI SARAWAK, 1841-1963
}

\author{
Ho Hui Ling
}

\begin{abstract}
Abstrak
This article examines the evolution of the Chinese in Saranak since the Brooke administration up to the formation of Malaysia. In the period 1841-1963, there was a change in status of the Chinese commnnity, from immigrants inoolved mainly in economic activities to prime movers in party politics in Sarawak. Eventhough the Chinese were not involved in local politics before the Second World War, they roere anare of political derelopments in China and the Sino-Japanese War in the 1930s. However, they were inoolved in forming social and economic organisations to protect their interests in Sarazuak. At that time, they paid more at tention to economic opportunities that could improwe their lioelihood. Furthermore, after the war and anidst the issue of cession of the state to the British, the Chinese still did not show any oboious interest in local politics. However, the conmunist movenent in Sarawak dominated by the Chinese worried the government and other etlmic groups. Next, the Chinese began to be involved in local politics when the local conncil elections were introduced by the British in the mid-1950s. By 1959, the Chinese nored to form the first political party in Sarawak, the SUPP (Sarawak United People's Party). The formation of the SUPP encouraged the Malays and Dayaks to form their oum parties to fight and protect the interests of their groups in Saranak. With that, the Chinese and the SUPP became prine movers in party politics in Sarawak.
\end{abstract}

\section{Pengenalan}

Sarawak merupakan sebuah negeri yang mempunyai latar belakang sejarah yang menarik. Sarawak sebelum tahun 1841 adalah di bawah kekuasaan Kesultanan Brunei. Bermula tahun 1841, Sarawak telah 
diperintah oleh keluarga Brooke, iaitu James Brooke, Charles Brooke dan Vyner Brooke. Selepas zaman pendudukan Jepun, Sarawak diserahkan kepada British dan menjadi tanah jajahan mahkota British pada 1 Julai 1946. British terus mentadbir Sarawak sehingga Sarawak mencapai kemerdekaan apabila Malaysia dibentuk pada 16 September 1963.

Masyarakat Sarawak dibentuk oleh penduduk berbilang kaum. Tiga kaum utama di Sarawak ialah Dayak, Cina dan Melayu. Orang Dayak adalah kumpulan penduduk teramai, diikuti dengan orang Cina dan kemudian orang Melayu. Kawasan tumpuan kebanyakan orang Cina adalah di kawasan bandar di seluruh negeri Sarawak. Orang Cina masuk ke Sarawak sebagai petani pada asalnya (kecuali di kawasan Bau), kemudian mereka turut mengambil bahagian dalam penanaman tanaman komersial dan perniagaan serta akhirnya dalam sektor pembalakan dan perlombongan minyak. Bilangan orang Cina bertambah dengan kadar yang stabil sehingga mereka membentuk kumpulan etnik yang kedua terbesar di Sarawak selepas kaum Dayak. Mereka bukan sahaja menguasai sektor-sektor ekonomi penting Sarawak tetapi kemudian juga mengambil bahagian dalam kegiatan politik dan seterusnya menjadi penggerak politik berparti di Sarawak pada lewat 1950-an.

\section{Orang Cina di Sarawak Sebelum Tahun 1941}

Pada sekitar tahun 1830-an, orang Cina telah berhijrah dari Sambas dan Pontianak di Kalimantan ke kawasan perlombongan emas di Bau, Sarawak. Mereka terdiri daripada orang Hakka yang bekerja di lombong emas di Bau, Kuching. Pada tahun 1857, dilaporkan terdapat hampir 4,000 orang Cina di Bau.' Mereka tidak bekerjasama dengan pemerintahan Brooke dan berniat untuk menggulingkan James Brooke daripada berkuasa di Sarawak apabila James Brooke cuba campur tangan dalam urusan mereka. Mereka menyerang ibu kota Sarawak, Kuching pada 18 Februari 1857 dan mencetuskan Pemberontakan Bau 1857. Walau bagaimanapun, sejak peristiwa pemberontakan sehingga James Brooke meninggal dunia pada tahun 1868, masih terdapat orang Cina yang masuk ke Sarawak. Ini kerana James Brooke sedar bahawa orang Cina selain menjadi pelombong, petani dan peniaga; mereka juga memberi sumbangan kepada hasil kerajaan melalui penjualan candu, arak dan aktiviti perjudian. ${ }^{3}$

Pada tahun 1871, kebanyakan perniagaan di Sarawak dan kilang memproses sagu adalah di bawah kawalan orang Cina. Pada tahun 1873, sebuah Dewan Perniagaan telah ditubuhkan di Kuching dan orang Cina membentuk kumpulan utama. Pada tahun 1878 pula, Raja Charles Brooke telah memperuntukkan sebuah kawasan luas kepada 
orang Cina untuk penanaman lada. ${ }^{4}$ Perkembangan ini menunjukkan orang Cina masih memainkan peranan penting dalam ekonomi Sarawak selepas peristiwa Pemberontakan Bau.

Penghijrahan orang Cina secara besar-besaran ke Sarawak bermula pada penghujung abad ke-19 dan awal abad ke-20. Raja Brooke khasnya Charles Brooke begitu kagum dan yakin akan semangat kegigihan orang Cina. Beliau berpendapat orang Cina dapat memberi sumbangan besar kepada pembangunan Sarawak. Oleh itu, beliau sangat menggalakkan kemasukan orang Cina ke Sarawak. Charles Brooke pernah menyatakan "The Chinaman would be equal to the master, or whiteman, if both worked fairly by sweat of his bow. Withont these people a tropical country would remain undeveloped." Selain itu, beliau juga menyatakan ". . intellectually the Chinese are our equals, are physically as strong, and I beliene, as brave; with surprising industry, energy, and actioity in commercial enterprises . .."6 Justeru itu, empat kumpulan imigran Cina diperkenalkan di bawah skim penghijrahan secara berkumpulan antara tahun 1898 dan 1912 oleh Charles Brooke.

Kumpulan pertama yang datang ke Kuching ialah orang Hakka pada tahun 1898. Ini diikuti dengan kemasukan tiga kumpulan orang Cina ke kawasan Rejang, iaitu orang Foochow pada tahun 1901, orang Kantonis pada tahun 1902 dan orang Henghua pada tahun 1912. Charles Brooke telah membuat perjanjian dengan ketua kumpulan tersebut untuk membawa masuk orang Cina itu ke kawasan Rejang bagi menerokai tanah pertanian. ${ }^{7}$ Selain daripada orang Cina yang masuk secara berkumpulan seperti di atas, terdapat satu lagi kumpulan orang Cina yang datang sendiri ke Sarawak untuk mencuba nasib dan memperbaiki kehidupan mereka. Mereka terdiri daripada orang Hakka, Foochow, Hokkien, Teochiu, Kantonis, Hainan, Henghua, Chao Ann, Luichow, Mandarin Selatan dan orang Shanghai. ${ }^{8}$

Penghijrahan orang Cina ke Sarawak diteruskan pada masa pemerintahan Vyner Brooke. Sebagaimana Charles Brooke, Vyner Brooke juga percaya orang Cina diperlukan dalam perkembangan ekonomi Sarawak. Malahan pada pertengahan tahun 1920-an, beliau menggalakkan kemasukan orang Foochow ke Baram dengan harapan membantu memajukan penanaman getah di kawasan itu. ${ }^{9}$ Bagaimanapun, sekatan ke atas penghijrahan masuk telah diketatkan terutamanya pada zaman kemelesetan ekonomi pada tahun 1929 dan 1931. Ramai orang Cina, khasnya yang sudah tua dan mempunyai keadaan fizikal tidak sesuai untuk bekerja di Sarawak dihantar pulang ke China. ${ }^{10}$ Perkembangan ini menyebabkan bilangan orang Cina yang berhijrah keluar lebih ramai daripada yang berhijrah masuk. Namun, keadaan telah berubah menjelang tahun 1935 , bilangan orang Cina yang berhijrah masuk melebihi mereka yang berhijrah keluar. 
Jadual 1 menunjukkan orang Cina yang berhijrah masuk dan keluar di Kuching dan Sibu di antara tahun 1930-1937. Pada tahun 1930, terdapat seramai 9,329 orang lelaki dan 1,351 orang wanita yang berhijrah keluar berbanding dengan 5,399 orang lelaki dan 1,529 orang wanita yang berhijrah masuk. Begitu juga, pada tahun 1931, bilangan yang berhijrah keluar lebih daripada yang berhijrah masuk. Terdapat 6,029 orang lelaki dan 1,564 orang wanita yang berhijrah keluar berbanding dengan 3,155 orang lelaki dan 1,020 orang wanita yang berhijrah masuk. Ini kerana berlakunya kemelesetan ekonomi. Namun, keadaan mulai berubah pada tahun 1935, bilangan orang Cina yang berhijrah masuk melebihi yang berhijrah keluar. Pada tahun 1935, sejumlah 5,170 orang Cina yang berhijrah keluar berbanding seramai 8,830 orang yang masuk ke Kuching dan Sibu. Pada tahun 1936 pula terdapat 8,955 orang yang berhijrah masuk manakala yang keluar berjumlah 6,370 orang. Seramai 14,108 orang Cina yang berhijrah masuk pada tahun 1937 berbanding dengan 6,982 orang yang keluar. Ini disebabkan oleh keadaan ekonomi Sarawak secara keseluruhan telah beransur-ansur pulih dan berjaya menarik lebih ramai orang Cina datang mencuba nasib di situ.

Jadual 1: Orang Cina yang Berhijrah Masuk/Keluar di Kuching dan Sibu, 1930-1937

\begin{tabular}{|c|c|c|c|}
\hline Tahun & $\begin{array}{c}\text { Hijrah Masuk } \\
\text { (orang) }\end{array}$ & $\begin{array}{c}\text { Hijrah Keluar } \\
\text { (orang) }\end{array}$ & $\begin{array}{c}\text { Hijrah Masuk/Hijrah Keluar } \\
\text { (orang) }\end{array}$ \\
\hline \multirow{2}{*}{1930} & 5,399 & 9,329 & $-3,930$ lelaki \\
\cline { 2 - 4 } & 1,529 & 1,351 & +178 wanita \\
\hline 1931 & 3,155 & 6,029 & $-2,874$ lelaki \\
\cline { 2 - 4 } & 1,022 & 1,564 & -544 wanita \\
\hline 1935 & 8,830 & 5,170 & $+3,660$ \\
\hline 1936 & 8,955 & 6,370 & $+2,585$ \\
\hline 1937 & 14,108 & 6,982 & $+7,126$ \\
\hline
\end{tabular}

Sumber: Samaak Administmtion Report, Kuching, 1938, hlm. 52.

Kedatangan orang Cina ke Sarawak telah mengubah corak kependudukan negeri ini. Jumlah orang Cina di Sarawak semakin bertambah sebagaimana yang dapat dilihat melalui Jadual 2. Pada tahun 1871, penduduk Sarawak berjumlah 141,546 orang dan antaranya orang Cina berjumlah 4,947 orang atau $3.5 \%$. Jumlah ini telah bertambah dengan kadar yang pesat sehingga mencapai $10.8 \%$ atau 45,000 orang daripada penduduk Sarawak yang berjumlah 416,000 orang pada tahun 1909. Dalam tempoh 30 tahun seterusnya, jumlah orang Cina meningkat lagi menjadi 123,626 orang atau $25.2 \%$ berbanding dengan 
490,585 orang jumlah penduduk Sarawak. Seterusnya, jumlah orang Cina telah bertambah kepada 145,158 orang $(26.6 \%)$ daripada jumlah penduduk Sarawak, 546,385 orang pada tahun 1947 dan 244,435 orang $(31.5 \%)$ daripada 776,990 jumlah keseluruhan penduduk Sarawak pada tahun 1962.

Jadual 2: Jumlah Penduduk Cina di Sarawak, 1871-1962

\begin{tabular}{|c|c|c|c|}
\hline Tahun & $\begin{array}{c}\text { Jumlah Penduduk } \\
\text { (orang) }\end{array}$ & $\begin{array}{c}\text { Orang Cina } \\
\text { (orang) }\end{array}$ & $\begin{array}{c}\text { Peratusan Daripada } \\
\text { Jumlah Penduduk } \\
\text { Sarawak }\end{array}$ \\
\hline 1871 & 141,546 & 4,947 & 3.5 \\
\hline 1909 & 416,000 & 45,000 & 10.8 \\
\hline 1939 & 490,585 & 123,626 & 25.2 \\
\hline 1947 & 546,385 & 145,158 & 26.6 \\
\hline 1962 & 776,990 & 244,435 & 31.5 \\
\hline
\end{tabular}

Sumber: Reports on Population Census 1960. Department of Statistic Malaysia (Sarawak Branch), hlm. 11. Lihat juga Vernon L. Porritt, The Rise and Fall of Communism in Saramak 1940-1990, Victoria, Australia: Monash University Press, $2004, \mathrm{hlm} .2$.

Bagaimanapun, sebelum tahun 1941, orang Cina tidak terlibat dalam politik Sarawak, sebaliknya tumpuan utama mereka adalah peluang ekonomi. Mereka mengambil bahagian dalam pelbagai kegiatan ekonomi; menjadi pelombong emas, penanam padi dan sayursayuran, pekebun lada dan getah, pembalak serta peniaga. Pada zaman pemerintahan Brooke, orang Cina sebagai pendatang dan tidak diberi atau dijanjikan apa-apa peranan rasmi dalam kerajaan. Tambahan pula, minat orang Cina dalam politik pada peringkat itu hanya tertumpu kepada perkembangan penting yang berlaku di Tanah Besar China dan bukan terhadap apa yang dianggap oleh mereka sebagai perubahan yang kurang penting di Sarawak. Namun demikian, dalam memelihara kepentingan dan kebajikan komunitinya, orang Cina bergiat dalam kegiatan berpersatuan dan sosial.

Kegiatan berpersatuan orang Cina bermula dengan penubuhan kongsi. Sebuah kongsi berpengaruh yang dikenali sebagai Twelve Company atau San-tiao Kou Kongsi telah dibentuk pada sekitar tahun 1830-an apabila bermulanya kegiatan melombong emas di Bau, Kuching. Kongsi ini berperanan sebagai badan yang mengurus hal ehwal orang Cina di Bau, khususnya dalam perlombongan. Selepas pemberontakan tahun 1857, kongsi itu ditamatkan setelah kerajaan mengenakan hukuman ke atas pemimpin dan ahli-ahlinya. "Dengan itu, telah wujud satu kekosongan sosial dan kekosongan ini telah diisi oleh orang Cina dengan pelbagai organisasi sosial yang wujud termasuklah pembinaan kuil, gereja, sekolah dan persatuan Cina. 
Orang Cina khasnya orang Hokkien membina tokong untuk menyembah tuhan mereka serta memohon perlindungan tuhan agar mereka dijauhkan daripada segala bahaya dan bencana. Pembinaan tokong juga adalah untuk memenuhi kehendak jiwa dan batin orang Cina apabila mereka sampai ke sesuatu kawasan baru. Di samping itu, tokong juga berfungsi sebagai tempat menjalankan upacara kelahiran, kematian dan perkahwinan. Melalui upacara-upacara itu dapat memberi peluang kepada orang Cina untuk berkumpul dan merapatkan hubungan sesama mereka. Orang Cina yang lain pula terlibat dalam usaha menubuhkan gereja. Mereka yang beragama Kristian menganggap gereja sebagai tempat penyatuan dan perlindungan. Mereka juga memerlukan gereja sebagai tempat menenangkan hati dan fikiran semasa menghadapi kesusahan di kawasan baru.

Selain itu, orang Cina mementingkan pendidikan untuk anak-anak bangsa dan sekolah didirikan dengan sumber kewangan mereka sendiri. Sebelum Perang Dunia Kedua, orang Cina di Sarawak menubuhkan sekolah berdasarkan kumpulan dialek masing-masing. Di Kuching, contohnya, Sekolah Free Hokkien ditubuhkan pada tahun 1912 untuk komuniti Hokkien, Sekolah Min Teck ditubuhkan pada tahun 1916 untuk komuniti Teochew, Sekolah Yik Kuan bagi komuniti Kantonis pada tahun 1918, Sekolah Kong Ming untuk komuniti Kaying Hakka dibina pada tahun 1921, Sekolah Tai Tung untuk komuniti Taipu Hakka dibina pada tahun 1923, Sekolah Yueh Kwang untuk komuniti Hakka ditubuhkan pada tahun 1936, Sekolah Kheng Kiow bagi komuniti Hainan ditubuhkan pada tahun 1922 dan Sekolah Chung Hua bagi pelbagai dialek pula ditubuhkan pada tahun 1937. Sementara itu, sekolah dialek di Sibu sebelum perang adalah ditubuhkan oleh orang Foochow. Sekolah-sekolah itu ialah Sekolah Chung Cheng (1906) dan Sekolah Chung Hua (1907). Di Kanowit juga terdapat sebuah sekolah dialek, iaitu Sekolah Rendah Khi Ting untuk komuniti Foochow yang ditubuhkan pada tahun 1919. Manakala, Sekolah Kai Wen untuk komuniti Foochow ditubuhkan di Binatang pada tahun 1922 dan Sekolah Sze Mei bagi komuniti Foochow di Sarikei pada tahun 1925. ${ }^{12}$

Berdasarkan dialek dan daerah asal, sebelum tahun 1940, terdapat beberapa persatuan Cina telah ditubuhkan. Antaranya, di Kuching telah ditubuhkan Persatuan Kong-Wei-Shiu (1853), Persatuan Hokkien (1871), Persatuan Kheng Chew (1898), Persatuan Teochew (1914), Persatuan Foochow (1930), Persatuan Hakka (1934) dan Persatuan Chao Ann (1936). Di Sibu pula terdapat Persatuan Kwang Wai Siew (1915), Persatuan Chiang Chuan Sibu (1933), Persatuan Kheng Chiew (1935), Persatuan Hui Hua Pou Sen Sibu (1938) dan Persatuan Hakka (1939). ${ }^{13}$ Persatuan seperti ini turut ditubuhkan di daerah-daerah lain di Sarawak sebelum Perang Dunia Kedua. Persatuan ini berfungsi 
sebagai tempat mereka berkumpul dan membincang perkara-perkara yang berkaitan dengan komunitinya sambil mengeratkan hubungan persaudaraan mereka.

Sementara itu, demi menjaga kepentingan ekonomi, orang Cina menubuhkan pertubuhan mereka sendiri. Antaranya, Kongkek yang dibentuk oleh pemimpin Hokkien dan Teochew seawal tahun 1876. Kongkek berfungsi untuk mengendalikan urusan penanaman dan perusahaan lada serta gambir. Pertubuhan ini juga berfungsi sebagai penghubung antara para penanam dengan pihak pentadbiran Brooke. ${ }^{14}$ Badan perniagaan lain yang ditubuhkan di Sarawak ialah Dewan Perniagaan Cina. Dewan Perniagaan Cina di Kuching didaftarkan pada 17 Mei $1930,{ }^{15}$ di Sibu pada 7 Ogos $1930,{ }^{16}$ di Baram pada 1 Mei 1929 dan di Miri pada 9 Mei 1929 serta Kelab Perniagaan Hua Ming di Sarikei pada 30 Mei $1930 .{ }^{17}$ Sebelum Perang Dunia Kedua, Dewan Perniagaan Cina berkhidmat sebagai penghubung antara kerajaan Brooke dengan para peniaga Cina.

Walaupun orang Cina tidak melibatkan diri dalam politik Sarawak, tetapi pada tahun 1930-an, orang Cina telah bersatu menumpukan perhatian dan tenaga kepada perubahan politik di China. Di China, pada tahun 1930-an, tentera Jepun menakluki Manchuria dan menubuhkan sebuah kerajaan boneka yang dikenali sebagai Manchukuo yang akhimya membawa kepada tercetusnya Perang China-Jepun pada tahun 1937. Dalam hal ini, orang Cina di Sarawak telah mengambil tindakan yang giat dengan menyalurkan bantuan untuk menentang Jepun. Mereka telah menubuhkan persatuan, memberi bantuan kewangan kepada China dalam menentang Jepun, memulaukan barangan buatan Jepun dan menghantar wakil untuk meninjau keadaan di China. Manakala, bagi belia-belia Cina yang bersemangat tinggi pula telah pulang ke China untuk menjadi tentera bersama-sama dengan tentera China menentang Jepun. Melalui Tabung Bantuan Kecemasan China yang ditubuhkan di Kuching dan Sibu, orang Cina telah mengadakan kutipan derma dan pementasan kebudayaan amal untuk mengumpul dana dalam membantu China melawan Jepun. Untuk itu, wang sebanyak $\$ 400,000$ telah dikumpul dan dihantar ke China melalui Singapura. ${ }^{18}$ Walau bagaimanapun, keadaan orang Cina di Sarawak mula berubah berikutan kemaraan tentera Jepun dan seterusnya pendudukan Sarawak oleh Jepun.

\section{Orang Cina Pada Zaman Pendudukan Jepun, 1941-1945}

Pada zaman pendudukan Jepun, orang Cina yang menyokong negara China dalam Perang China-Jepun telah menjadi sasaran kekejaman pihak Jepun. Mereka berdepan dengan tekanan dan kegiatan kekejaman 
Jepun. Jepun menjalankan operasi pembersihan atau sook ching terhadap orang Cina di Sarawak. Menurut Yoji Akashi dalam "Japanese Policy Towards The Malayan Chinese 1941-1945", tindakan tersebut diambil oleh pentadbiran tentera Jepun untuk mengekalkan keamanan kerana takut orang Cina mengangkat senjata menentang mereka. ${ }^{19}$

Tentera Jepun juga melakukan kekerasan terhadap pemimpin Cina yang mengambil bahagian dalam kempen anti-Jepun di China dan Tanah Melayu. Mereka yang disyaki terlibat telah ditangkap, ditahan dan dipenjarakan. Contoh mereka yang dilayan dengan kejam ialah Chien Chang Poa, Pengerusi Tabung Bantuan Kecemasan China. Khan Ah Chong y ang enggan meminta maaf bagi kegiatan anti-Jepun sebelum perang juga telah dilayan dengan kejam. ${ }^{20} \mathrm{Ngu}$ San Tieh yang disyaki mencuri bendera Jepun dari dewan panggung wayang di Sibu pada Disember 1943, ditahan dan diseksa oleh tentera Jepun sehingga mati. ${ }^{21}$

Selain itu, orang Cina turut menghadapi tekanan sosial pada zaman penjajahan Jepun. Pemimpin, peniaga, pekerja, guru dan golongan intelek berbangsa Cina di Kuching, Sibu dan bandar-bandar utama di Sarawak diaralhkan menyertai kelas bahasa Jepun serta menghadiri sesi pemulihan dan sivik yang diaturkan oleh pihak pentadbiran Jepun. Pada masa yang sama, sekolah Cina turut diubah dan digunakan untuk mengajar bahasa Jepun di samping sebagai pusat propaganda Jepun kepada penduduk..$^{22}$ Persatuan-persatuan Cina pula sama ada ditutup atau hanya wujud dari segi namanya sahaja. Sebagai gantinya mereka dipaksa membentuk persatuan yang dinamakan Kakyo Kyokai (United Overseas Chinese/Persatuan Orang Cina Seberang Laut). Persatuan ini dikendalikan oleh sebuah jawatankuasa yang terdiri daripada ketua lima buah persatuan dialek Cina, iaitu persatuan Hokkien, Kantonis, Hainan, Teochew dan Hakka yang dilantik oleh pihak Jepun. ${ }^{23}$ Melalui penubuhan persatuan itu, Jepun bertujuan untuk mengawal aktiviti orang Cina dan memastikan mereka tidak dapat bergerak untuk menentang pihak Jepun.

Dalam pada itu, orang Cina dikenakan wang denda atas bantuan mereka kepada China ketika Perang China-Jepun. Dalam hal ini, orang Cina di Sarawak dikenakan sejumlah $\$ 1,900,000$ wang denda oleh pihak pentadbiran Jepun. Ini termasuklah orang Cina di Kuching dikenakan denda $\$ 900,000$, Sibu sebanyak $\$ 700,000$ dan Miri berjumlah $\$ 300,000 .{ }^{24}$ Dengan itu, orang Cina bukan sahaja berdepan dengan tekanan sosial dan kekejaman Jepun, tetapi juga tekanan ekonomi kesan daripada tuntutan pembayaran wang denda oleh Jepun ketika zaman penjajahannya di Sarawak.

Dalam perkembangan lain, pentadbiran Jepun mengamalkan dasar diskriminasi terhadap orang Cina. Ini dapat dilihat melalui dasar cukai kepala yang dikenakan ke atas penduduk tempatan. Setiap orang 
Cina dikenakan cukai kepala sebanyak $\$ 6$ setahun berbanding dengan penduduk Bumiputera yang cuma perlu membayar 50 sen setahun. Orang Cina juga ramai yang dijadikan buruh paksa untuk membina jalan raya dan padang pendaratan kapal terbang perang Jepun di Sarawak. Pada tahun 1945, dianggarkan seramai 3,000 orang Cina dan Jawa yang dijadikan buruh paksa ini mati kebuluran di Miri. ${ }^{25}$

Kesan daripada kesempitan hidup semasa pendudukan Jepun telah menyedarkan orang Cina tentang pentingnya penyatuan dalam kalangan mereka di Sarawak. Tambahan pula kegagalan pihak British dalam menyekat kemaraan Jepun di Sarawak dilihat sebagai satu kelemahan dan secara tidak langsung telah membuat mereka beralih kepada China sebagai orientasi nasionalisme mereka. Justeru itu, apabila tentera Australia memasuki Kuching pada September 1945, mereka mendapati jalan-jalan diaturkan dengan bendera China berbanding dengan bendera British atau Sarawak. Keadaan ini telah mendatangkan perasaan kurang senang hati dalam kalangan kaum-kaum lain di Sarawak.

Di Saratok, Simanggang dan Betong, bendera nasionalis China dinaikkan dengan segera setelah bendera Jepun diturunkan sebagai tanda pendaratan dan pengambilan alih oleh orang Cina. ${ }^{26}$ Selain itu, perasaan patriotik orang Cina Sarawak dapat dilihat melalui kegiatan yang dijalankan sempena menandakan kekalahan pihak Jepun dalam Perang Dunia Kedua. Mereka mengadakan perarakan dan pertunjukan kebudayaan, melancarkan kempen mencintai negara China, menganjurkan pertandingan pasukan bola keranjang serta lawatan di antara pemuda-pemudi Sibu dengan Kuching. ${ }^{27}$ Di samping itu, akhbar Cina seperti Sibu Chiao Sheng Pau turut memainkan peranan dalam menyebarkan semangat mencintai negara China. Melalui aktiviti ini, semangat keChinaan dapat ditanam dalam kalangan orang Cina di Sarawak dan mereka berasa megah dengan kejayaan China menewaskan Jepun dalam perang. Dengan itu, jelas bahawa penjajahan dan kemudian kekalahan Jepun telah meningkatkan semangat nasionalisme dalam kalangan orang Cina tetapi semangat itu hanya ditujukan kepada China dan bukannya Sarawak.

Sebagai contohnya, di Kuching, pada 10 Oktober 1945 telah diraikan "Joint Allied Victory and Chinese National Day". ${ }^{28}$ Pentas rendah dihias dengan bendera nasionalis bersama-sama dengan bendera British dan Australia. Ucapan kepada orang ramai diberikan oleh beberapa orang pemimpin Cina termasuk Ong Tiang Swee. Aktivitiaktiviti lain juga telah diatur seperti pertandingan sukan, makan malam di rumah Ong Tiang Swee dan pertandingan konsert. Sambutan yang sama juga diadakan di Miri sebelum itu, iaitu pada 21 September $1945 .^{29}$ Oleh itu, tidak dapat dinafikan bahawa orang Cina di peringkat ini 
lebih cenderung kepada perkembangan politik di China. Mereka juga telah menunjukkan sikap bersatu dan seterusnya berjaya meningkatkan semangat kebangsaan yang ditunjukkan kepada China dalam kalangan orang Cina Sarawak.

Zaman pendudukan Jepun telah meninggalkan kesan penting dalam masyarakat Cina di Sarawak. Selain meningkatnya semangat nasionalisme, usaha ke arah penyatuan orang Cina juga mula kelihatan dalam kegiatan mereka. Selepas pendudukan Jepun, orang Cina lebih cenderung bersatu di bawah satu organisasi berbanding dengan sebelumnya, mereka lebih berminat dengan pertubuhan berlandaskan tujuan ekonomi atau untuk tujuan satu-satu kumpulan loghat. Dua pertubuhan penting telah ditubuhkan pada tahun 1946 untuk menyalurkan suara hati orang Cina yang mula menuntut hak politik dan sosial, iaitu Persatuan Chung Hua dan Hua Kheow Tshin Nien (Overseas Chinese Youth Association). Antara isu-isu yang dibangkitkan oleh kedua-dua pertubuhan itu ialah hak politik orang Cina, hak kerakyatan dan juga pendidikan orang Cina di Sarawak. Hua Kheow Tshin Nien telah ditubuhkan di Kuching dan pusat-pusat lain di Sarawak menjelang awal tahun 1946. Pertubuhan itu telah didaftarkan di Kuching pada 25 Mei 1946 dan juga ditubuhkan di Binatang, Bau, Batu 10 Jalan Penrissen Kuching dan Batu Kawa di Kuching. ${ }^{30}$ Pertubuhan yang dianggotai oleh pemuda-pemudi Cina itu percaya bahawa sistem pemerintahan demokrasi yang diingini oleh mereka lebih berpeluang menjadi kenyataan di bawah kerajaan kolonial. Oleh itu, kumpulan ini kemudian telah bersedia menyokong penyerahan Sarawak kepada kerajaan Britain. ${ }^{37}$

Empat bulan selepas Jepun menyerah diri, wakil daripada 24 buah persatuan dialek Cina telah dipanggil berhimpun untuk membentuk sebuah pertubuhan pusat Cina di Kuching. Tujuannya ialah untuk memudahkan pihak pentadbiran berhubung secara langsung dengan orang Cina Sarawak berbanding dengan berhubung melalui persatuan dialek Cina. Hasilnya, Persatuan Chung Hua telah dibentuk dan didaftarkan di Kuching pada 21 Mei 1946. Persatuan Chung Hua di Bintulu pula didaftarkan pada 1 April 1947 dan Persatuan Chung Hua di Lundu didaftarkan pada bulan September 1947.32 Persatuan itu berfungsi sebagai perantaraan orang Cina dengan kerajaan Sarawak. Melaluinya, pandangan secara langsung dapat disalurkan kepada pihak berkuasa berbanding dengan melalui persatuan dialek Cina yang pelbagai. Orang Cina turut menyampaikan masalah mereka yang selama ini kurang ditekankan oleh Dewan Perniagaan Cina kepada Persatuan Chung Hua. ${ }^{33}$ 


\section{Reaksi Orang Cina Terhadap Isu Penyerahan Sarawak Kepada British}

Selepas Perang Dunia Kedua, Vyner Brooke mengambil keputusan menamatkan pemerintahan keluarga Brooke dan menyerahkan pentadbiran Sarawak kepada British. Keputusan Raja Brooke itu menyebabkan Sarawak dijadikan sebuah tanah jajahan mahkota British bermula pada 1 Julai 1946. ${ }^{34}$ Perkembangan tersebut membawa kepada kemunculan penentangan daripada penduduk tempatan Sarawak dan menyebabkan meletusnya Gerakan Anti-Penyerahan. Kemuncak kepada gerakan penentangan itu ialah pembunuhan Gabenor Duncan Stewart di Sibu pada 3 Disember 1949. Yang mengepalai gerakan penentangan itu ialah orang Melayu Sarawak di bawah Persatuan Kebangsaan Melayu Sarawak (PKMS) dan disokong oleh sebilangan orang Dayak di bawah Sarawak Daynk Association (SDA). Kumpulan penentang itu datangnya dari Bahagian Pertama dan Ketiga Sarawak. ${ }^{35}$

Dalam pergolakan itu, orang Cina menunjukkan reaksi yang dingin dan tiada tentangan yang nyata. Ini kerana pada peringkat itu orang Cina masih kurang berminat terhadap politik Sarawak dan tidak ingin terlibat secara langsung dalam pergerakan politik tempatan. Apa yang lebih penting bagi mereka ialah perkara-perkara yang berkaitan dengan kehidupan mereka di Sarawak seperti ekonomi dan bukan masalah politik..$^{36}$ Bagaimanapun, terdapat segolongan orang Cina yang menyatakan sokongan kepada penyerahan Sarawak. Bagi golongan ini, melalui penyerahan Sarawak kepada British, Sarawak akan memperoleh kebaikan dari segi ekonomi, khasnya dalam bidang teknikal, juga pendidikan dan kewangan. Golongan ini juga sedar bahawa penyerahan itu dapat membebaskan mereka daripada penguasaan politik oleh kaum Bumiputera. Ini kerana penyerahan Sarawak dapat membuka peluang kepada penglibatan orang Cina dalam pentadbiran Sarawak dan memberi kuasa politik kepada mereka. ${ }^{37}$

Dengan itu, jelas bahawa munculnya kumpulan orang Cina yang menyokong penyerahan Sarawak kepada kerajaan British kerana mereka menganggap penyerahan itu adalah baik. Ini dapat dilihat melalui kata-kata Khoo Peng Loong, wakil orang Cina di Bahagian Ketiga Sarawak ketika itu. Dalam hal ini, beliau menyatakan:

As I am a representative of the Chinese in the Rejang River District, I give my support to the Cession for under the British Rule the two main vices, gambling and opium, will be abolished and the status of the Chinese will be raised to the same position as that of the natives of Sarawak. Under the British Rule there will be better education, better agriculture and vaster development of the country to the general advantage of all the people in the country. ${ }^{38}$ 
Sementara itu, Ong Tiang Swee, seorang pemimpin Cina di Kuching, berpendapat perubahan Sarawak kepada sebuah negeri bertaraf koloni adalah bermaksud perkembangan ekonomi dan perdagangan yang lebih meluas. ${ }^{39}$ Anaknya, Ong Kwan Hin dan Datuk Amar Hong Guan Lin juga menyokong penuh penyerahan Sarawak kerana Sarawak akan memperoleh faedah melalui hubungan dengan sebuah kuasa kuat yang dapat menstabilkan kedudukan ekonomi negeri ini dan kemajuan Sarawak juga akan terjamin. Mereka menyatakan cukai dan hasil kerajaan tidak dapat menampung perbelanjaan membangun semula Sarawak kerana sektor utama ekonomi telah musnah akibat perang. Justeru itu, mereka berpendapat Sarawak adalah sebuah negeri yang bankrap, hanya Britain sahaja mampu menyediakan modal yang dikehendaki untuk pemulihan semula dan pembangunan Sarawak. ${ }^{40}$ Oleh itu, mereka menyatakan penyerahan Sarawak adalah perlu dilakukan.

Mewakili persatuan Hua Kheow Tshin Nien, Lim Kong Ngan mengkritik pemerintahan Brooke adalah bersifat autokratik dan ketinggalan zaman serta menyebabkan Sarawak mundur dalam segala aspek seperti kebudayaan, pendidikan, ekonomi dan perhubungan. Beliau menyokong penyerahan Sarawak sekiranya penyerahan mendatangkan kemajuan dan perubahan serta membolehkan penduduk Sarawak mengambil bahagian dalam politik. Dengan itu, beliau berharap sistem demokrasi yang sebenar dapat dilaksanakan di bawah pentadbiran British. ${ }^{41}$ Manakala, Teo Chong Loh, Kapitan Cina Sibu, ketika bercakap bagi pihak orang Cina di Sibu, menyatakan sokongan terhadap penyerahan Sarawak. Beliau menegaskan bahawa penyerahan Sarawak adalah sesuatu yang diingini dan dinanti-nantikan oleh mereka. Dalam pada itu, penduduk Cina di Kapit juga bersetuju dengan keputusan Raja Brooke menyerahkan Sarawak kepada British. Mereka berpendapat bahawa tindakan menyerahkan Sarawak adalah untuk menjaga keamanan dan pembangunan di negeri itu. ${ }^{42}$

Dalam perkembangan lain, terdapat sekumpulan orang Cina yang masih taat setia kepada China dan peka terhadap perubahanperubahan yang berlaku di China. Mereka yang termasuk dalam kumpulan ini ialah orang Cina yang menerima sistem pendidikan Cina. Kumpulan ini tidak berpendapat pemerintahan British adalah lebih baik daripada pemerintahan Brooke. Sebaliknya, pemikiran politik mereka pada masa itu adalah lebih cenderung kepada perkembangan komunis di China. Mereka ini berpendapat hanya kerajaan komunis sahaja yang dapat membawa pemerintahan yang lebih baik kepada negeri Sarawak. Manakala, orang Cina yang dipengaruhi oleh komunis menentang penyerahan Sarawak kerana mereka bercita-cita membentuk sebuah negara komunis di Sarawak. ${ }^{43}$ Walau bagaimanapun, akhirnya 
kehendak Raja Vyner Brooke berhasil dan Sarawak diserahkan kepada kerajaan Britain untuk dijadikan tanah jajahan mahkota British sehingga pembentukan Malaysia.

Secara keseluruhannya, tidak dapat dinafikan bahawa reaksi orang Cina terhadap peristiwa penyerahan Sarawak kepada kerajaan British adalah tidak begitu menonjol dan tidak sehebat komuniti Melayu yang membawa kepada peristiwa pertumpahan darah. Orang Cina pada ketika itu hanya sekadar menunjukkan sokongan atau perasaan tentangan mereka melalui media massa terutamanya akhbar dan tidak mengambil bahagian dalam gerakan anti-penyerahan.

\section{Penglibatan Orang Cina Dalam Gerakan Komunis}

Selepas perang, pihak kerajaan berasa bimbang tentang perkembangan komunis dan penyerapan ideologi komunis dalam kalangan orang Cina Sarawak. Ideologi itu masuk ke Sarawak melalui pelbagai saluran, seperti sekolah, organisasi dan media massa yang boleh menimbulkan kekacauan di negeri ini. Ini kerana Sarawak terdedah kepada pengaruh komunis dari tanah besar China memandangkan terdapat penduduk Cina yang ramai dan mengekalkan hubungan rapat dengan China. Perkembangan ini telah menimbulkan kebimbangan pihak kerajaan kerana guru, pemuda-pemudi dan pelajar yang cenderung kepada politik China dan dipengaruhi oleh perjuangan Parti Komunis China (PKC). Pada masa yang sama, ideologi komunis juga meresap ke dalam kesatuan sekerja dan cuba mempengaruhi tenaga buruh di Sarawak. ${ }^{44}$

Pergerakan komunis di Sarawak telah bermula sejak zaman pendudukan Jepun lagi. Aktivitinya banyak disertai oleh petanipetani miskin yang tertarik dengan idea perjuangan komunis, iaitu masyarakat sosialis dan tanpa kelas. Majoriti daripada mereka ialah petani-petani Hakka yang tinggal di kawasan Batu Kawa di luar bandar Kuching. ${ }^{45}$ Pergerakan komunis di Sarawak muncul dengan giat berikutan dengan kejayaan pembentukan kerajaan komunis di China, iaitu Republik Rakyat China (RRC) pada Oktober 1949.46 Pada tahun 1950, RRC menghantar wakil untuk menyeru orang Cina seberang laut supaya terus menyokong China. Keadaan itu mendorong golongan pemuda Cina menyusun sebuah persatuan persahabatan pro-Peking yang dikenali sebagai Sarnwak Overseas Chinese Democratic Youth Lengue (SOCDYL) pada 21 Oktober 1951. Tujuannya ialah untuk menyebarkan fahaman komunis dan mengeksploitasi keadaan yang boleh menguntungkan perjuangan komunis. ${ }^{47}$

Kesan tekanan daripada kerajaan, SOCDYL telah dibubarkan dan diganti dengan Sarawak Liberation League (SLL) yang dibentuk pada Mac 1954. SLL bertujuan untuk memperkuatkan barisan perjuangan 
komunis di Sarawak. Selain mempengaruhi penuntut sekolah, mereka turut menjadikan petani dan pekerja sebagai sasaran kerana kedua-dua golongan ini diperlukan untuk mencapai matlamat perjuangan mereka. SLL pula kemudiannya diganti oleh sebuah pertubuhan komunis lain, iaitu Sarawak Adranced Youth Association (SAYA) yang dibentuk pada tahun 1956. SAYA dikenali oleh pihak kerajaan Sarawak sebagai Pertubuhan Sulit Komunis (Clandestine Communist Organisation/CCO) dan Sarawak Communist Organisation (SCO). Matlamat utama ialah membebaskan Sarawak daripada belenggu penjajahan dan membentuk sebuah negara komunis yang merdeka. ${ }^{48}$

Pengaruh komunis dalam kalangan orang Cina dapat dilihat melalui penglibatan mereka dalam menimbulkan kekacauan yang berlaku di Sekolah Chung Hua Kuching pada tahun 1951, penerbitan akhbar yang dipengaruhi unsur komunis dan perjumpaan buku serta dokumen komunis yang disimpan oleh orang Cina. Pada tahun 1951, kerajaan mendakwa Persatuan Pelajar Sekolah Chung Hua Kuching dipengaruhi fahaman komunis. Pihak pengurusan sekolah hilang kawalan terhadap sekolah itu apabila pelajar mendesak supaya mempertimbangkan semula keputusan peperiksaan bahasa Inggeris yang majoritinya gagal. Sebahagian daripada pelajar itu mula mengadakan demonstrasi dan mengakibatkan seramai 17 orang pelajar dibuang sekolah serta enam orang ditahan. Bagaimanapun, desakan itu membawa kepada pembentukan Lembaga Pengurusan Sekolah baru pada 17 Januari 1952. Persatuan Belia Cina Seberang Laut Kuching yang menyokong pelajarpelajar itu juga diisytiharkan sebagai pertubuhan menyalahi undangundang pada Februari 1952 oleh kerajaan. Berikutnya, pengetua dan lima orang guru Sekolah Chung Hua di Batu 17, Kuching juga ditahan kerana disyaki terlibat dalam kegiatan tersebut. Manakala, tiga orang guru yang lain pula dibuang negeri. Sekolah Chung Hua kemudian telah diarahkan ditutup pada Ogos $1954{ }^{49}$

Pihak komunis juga menyokong akhbar Cina di Sarawak sebagai alat propaganda pro-komunis. Akhbar pertama di bawah pengaruh komunis yang muncul selepas perang ialah Chung Hua lournal/Chung Hua Kung Pao tetapi telah diberhentikan penerbitannya oleh kerajaan pada tahun 1951. Di samping itu, Sin Wen Pan di Kuching yang diterbitkan pada tahun 1959; Min Chong Pau di Sibu pada tahun 1960 dan Sa Min Pal di Miri pada tahun 1961 juga mendapat sokongan golongan komunis. ${ }^{50}$ Akhbar itu digunakan untuk menyebarkan idea komunis di kawasan bandar yang mempunyai penduduk Cina yang ramai. Namun demikian, ketiga-tiga akhbar itu kemudiannya telah diberhentikan penerbitan oleh pihak kerajaan pada Disember 1962."

Turut dilaporkan bahawa pihak polis telah menjumpai kira-kira 300 buku komunis yang termasuk dalam senarai larangan dalam satu 
serbuan di kawasan Batu 17 Jalan Kuching/Serian. ${ }^{52}$ Begitu juga dua orang pelajar Cina berumur 22 tahun bernama Tan Yiang Meng dan Chan Wan Leung ditangkap kerana didapati menyimpan buku-buku yang diharamkan oleh pihak kerajaan, iaitu buku bertajuk Cultivation and Development of Will Power and Personality (China: The Youth Publishing Society) dan Rudimental Knowledge of Philosophy (Shantung People's Publishing Society). ${ }^{53}$ Di samping itu, seorang gadis Cina bernama Tan Suk Kim telah ditangkap dan dihadapkan ke mahkamah kerana didapati memiliki dokumen komunis. Antara dokumen yang dirampas oleh pihak berkuasa adalah "Revolutionary Struggle" dan "To Strive for the Early Liberation of our Mother Country". ${ }^{54}$

Selepas perang, pandangan orang Cina terhadap politik tempatan masih tidak jelas. Namun demikian, melalui penglibatan mereka dalam gerakan komunis telah menampakkan pengaruh China masih kuat dalam kalangan mereka. Mereka yang terpengaruh dan dipengaruhi oleh komunis cuba menyebarluaskan pengaruh itu khasnya dalam kalangan orang Cina ke arah mencapai matlamat untuk menubuhkan sebuah kerajaan komunis di Sarawak.

\section{Penglibatan Orang Cina Dalam Pilihan Raya}

Dalam pada itu, perkembangan dalam masyarakat Cina turut dipengaruhi oleh ucapan Presiden China, Zhou En-lai kepada orang Cina seberang laut pada tahun 1955. Beliau mengkehendaki orang Cina memberi taat setia dan mengambil bahagian dalam politik tempatan di negara mereka berada itu. Dalam hal ini, beliau telah menyatakan:

The relationship between China and overseas Chinese is likened to one between parents and their off-springs: when children have grown up, parents don't like their children to stay with them forever; they should do something in the outside world. Similarly, China would like to see overseas Chinese standing on their own feet; they should develop and take roots outside China. They must respect the local laws, behave as loyal citizens and take part in the political activities there. ${ }^{55}$

Ucapan Zhou itu meninggalkan kesan yang penting dalam sanubari orang Cina. Perkembangan itu telah menyebabkan perubahan pandangan dan sikap orang Cina terhadap Sarawak. Tidak dapat dinafikan itulah faktor penting yang membawa kepada penglibatan orang Cina dalam politik tempatan dengan lebih serius kerana mereka mula memikirkan kedudukan dan masa depan mereka di negeri ini. Ini dapat dilihat melalui penglibatan mereka dalam politik Sarawak yang bertambah rancak apabila pilihan raya tempatan diperkenalkan 
pada tahun 1956 dan disusuli dengan penubuhan parti politik pertama pada tahun 1959.

Pada tahun 1956, pilihan raya tempatan pertama diadakan di Sarawak sebagai persediaan awal ke arah berkerajaan sendiri. Pilihan raya ini diadakan bagi Kuching Municipal Council (KMC) pada tahun 1956 dan seterusnya bagi Sibu Urban District Council (SUDC) pada tahun berikutnya. Pemimpin-pemimpin Cina telah berebut-rebut untuk menjadi calon dan orang Cina berkeinginan memilih wakil-wakil mereka dalam majlis tempatan tersebut.

Untuk tujuan pilihan raya $\mathrm{KMC}$, Kuching dibahagikan kepada sembilan kawasan (ward). Dalam tujuh kawasan yang didominasi oleh orang Cina, ahli-ahli majlis Cina dipilih. Manakala, ahli-ahli Melayu dipilih dalam dua kawasan (Datu dan Mosque) yang majoriti penduduknya adalah orang Melayu. Dalam pilihan raya KMC, di antara 12 calon Melayu hanya enam sahaja yang berjaya berbanding dengan 21 calon Cina yang berjaya dipilih. Di antara wakil Melayu yang dipilih ialah Dawi bin Abdul Rahman, Mohamad bin Haji Bakri, Ikhwan bin Zaini, Haji Su'ut Tahir, Ahmad Zaidi Adruce dan Haji Mohamad Rambli bin Haji Leman. Wakil Cina yang berjaya menduduki KMC terdiri daripada William Tan, Teo Kui Seng, Kong Yu Siong, Henry Ong Kee Chuan, John Lee Nyuk Syn, Ee Ghim Yam, Law Heng Choon, Fan Kuan Ling, Chin Poh Luke, Lo Foot Kee, Song Thian Cheok, Ong Kee Hui, Tan Tak Seng, Song Thian Ho, Goh Hong Kee, Stephen Yong Kuet Tze, Shii Dai Seng, Francis Tan Eng Chong, Yeo Cheng Hoe, Chan Siaw Hee dan Sim Joo Sek.

Jadual 3 menunjukkan nama-nama calon yang berjaya menduduki KMC berdasarkan kawasan. Keputusan pilihan raya ini telah menunjukkan keanggotaan KMC didominasi oleh orang Cina. Selepas pilihan raya tersebut, William Tan dipilih sebagai Pengerusi pertama KMC dengan Ong Kee Hui sebagai timbalannya. ${ }^{56}$ Keadaan itu menjelaskan bahawa pilihan raya KMC telah dimenangi oleh orang Cina dan merekalah yang mengetuai serta membentuk majoriti ahli dalam KMC.

Pada tahun berikutnya, pilihan raya yang serupa juga diadakan di Sibu bagi SUDC, iaitu pada 15 Disember 1957. Seramai 50 orang calon bersaing untuk 20 kerusi yang dipertandingkan. Dalam pilihan raya itu, Sibu dibahagikan kepada sembilan kawasan (ward). Keputusan pilihan raya menunjukkan keanggotaan SUDC adalah dimonopoli oleh orang Cina, 16 daripada 20 ahlinya terdiri daripada orang Cina. Mereka ialah Yew Kheng Sui, Pang Ming Seng, Law Hieng Ing, Tieu Sung Seng, Peter Jong Kuet Siong, Ngu Tieng Eng, Teng Kah Eng, Ting Chew Hin, Wong Ngi Chang, Chang Ta Kang, Kong Sung Seng, Ting Lik Hung, Chew Geok Lin, Lee Yu Yong, Kong Chung Siew dan Chieng Hie Kwong. 
Manakala ahli Melayu terdiri daripada Abang Haji Abdul Razak, Abang Kiprawi bin Datu Abang Yan, Ainnie bin Dhoby dan V.G. Bandong.

Jadual 3: Senarai 27 orang Calon yang berjaya dalam Pemilihan Kuching Municipal Council (KMC) Berdasarkan Kawasan (Ward)

\begin{tabular}{|l|l|}
\hline Kawasan (Ward) & Nama Calon \\
\hline Ward No. 1 (Datu) & $\begin{array}{l}\text { Dawi hin Abdul Rahman } \\
\text { Mohamad bin Haji Bakri } \\
\text { Ikwan bin Zainie }\end{array}$ \\
\hline Ward No. 2 (Mosque) & $\begin{array}{l}\text { Haji Su'ut Tahir } \\
\text { Ahmad Zaidi Adruce } \\
\text { Haji Mohamad Rambli bin Haji Leman }\end{array}$ \\
\hline Ward No.3 (Satok South) & $\begin{array}{l}\text { William Tan } \\
\text { Teo Kui Seng } \\
\text { Kong Yu Siong }\end{array}$ \\
\hline Ward No.4 (Rock) & $\begin{array}{l}\text { Henry Ong Kee Chuan } \\
\text { Jolu Lee Nyuk Syn } \\
\text { Ee Ghim Yam }\end{array}$ \\
\hline $\begin{array}{l}\text { Ward No.5 } \\
\text { (Market) }\end{array}$ & $\begin{array}{l}\text { Law Heng Choon } \\
\text { Fan Kuan Ling } \\
\text { Chin Poh Luke }\end{array}$ \\
\hline $\begin{array}{l}\text { Ward No.6 } \\
\text { (Bazaar) }\end{array}$ & $\begin{array}{l}\text { Lo Foot Kee } \\
\text { Song Thian Cheok } \\
\text { Ong Kee Hui }\end{array}$ \\
\hline Ward No.7 (Padungan) & $\begin{array}{l}\text { Tan Tak Seng } \\
\text { Song Thian Ho } \\
\text { Goh Hong Kee }\end{array}$ \\
\hline Ward No.8 (Central) & $\begin{array}{l}\text { Stephen Yong Kuet Tze } \\
\text { Shii Dai Seng } \\
\text { Francis Tan Eng Chong }\end{array}$ \\
\hline $\begin{array}{l}\text { Yeo Cheng Hoe } \\
\text { Chan Siaw Hee } \\
\text { Sim Joo Sek }\end{array}$ \\
\hline
\end{tabular}

Sumber: Samwak By The Week, 4 November-10 November 1956, hlm. 2. Lihat juga Utusan Sarawak, 7 November 1956 , hlm. 2.

Selepas pemilihan ahli majlis, dua orang Cina, iaitu Ting Chew Huat telah dipilih sebagai Pengerusi SUDC dan John Loo Liing Chong sebagai timbalannya. ${ }^{57}$ Keputusan pilihan raya SUDC dapat dilihat dalam Jadual 4. 
Jadual 4: Nama 20 orang calon yang berjaya dalam pemilihan Sibu Urban District Council (SUDC) Berdasarkan Kawasan (Ward)

\begin{tabular}{|l|l|}
\hline Kawasan (Ward) & Nama Calon \\
\hline Ward 1 (Upper Island) & $\begin{array}{l}\text { Yew Kheng Sui } \\
\text { Pang Ming Seng }\end{array}$ \\
\hline Ward 2 (Lower lsland) & $\begin{array}{l}\text { Law Hieng Ing } \\
\text { Tieu Sung Seng }\end{array}$ \\
\hline Ward 3 (Upper Kampongs) & $\begin{array}{l}\text { Abang Haji Abdul Razak } \\
\text { Abang Kiprawi bin Datu Abang Yan }\end{array}$ \\
\hline Ward 4 (Lower Kampongs) & $\begin{array}{l}\text { Ainnie bin Dhoby } \\
\text { V.G. Bandong }\end{array}$ \\
\hline Ward 5 (Race Course) & $\begin{array}{l}\text { Peter Jong Kuet Siong } \\
\text { Ngo Tieng Eng }\end{array}$ \\
\hline Ward 6 (Sungei Merah) & $\begin{array}{l}\text { Teng Kah Eng } \\
\text { Ting Chew Hin }\end{array}$ \\
\hline Ward 7 (Bukit Assek) & $\begin{array}{l}\text { J. Wong Ngi Chang } \\
\text { Chang Ta Kang } \\
\text { Kong Sung Seng }\end{array}$ \\
\hline Ward 8 (Lanang Road) & $\begin{array}{l}\text { Ting Lik Hung } \\
\text { Chew Geok Lin } \\
\text { Lee Yu Yong }\end{array}$ \\
\hline Ward 9 (Salim) & $\begin{array}{l}\text { Kong Chung Siew } \\
\text { Chieng Hie Kwong }\end{array}$ \\
\hline
\end{tabular}

Stmber: The Sarauak Gonernncht Gazette Lxtruordinam, Part IV, Vol, XII, No. 27, 31 December 1957, hlm. 215. Lihat juga Sarawak By Thw Week, 15 December-21 December 1957, hlm. 2.

Tindakan kerajaan untuk mengadakan pilihan raya telah mendapat sambutan yang menggalakkan daripada orang Cina dan kaum lain seperti Melayu serta Dayak. Ini adalah kerana melalui pilihan raya itu rakyat boleh memilih wakil masing-masing dalam kerajaan. Pilihan raya juga memberi mereka peluang mengambil bahagian dalam politik tempatan. Ramai intelek Cina termasuklah mereka yang berpendidikan Cina dan Inggeris telah berebut-rebut untuk bertanding sebagai calon. Ini jelas menunjukkan orang Cina bukan sahaja mula berminat terhadap politik tempatan malah mereka juga mula terlibat secara langsung dalam perkembangan politik Sarawak. Mereka ini kemudian terus bergiat dalam politik sehingga menjadi pelopor kepada gerakan politik berparti di Sarawak.

\section{Penubuhan Parti Politik dan Penglibatan Dalam Pilihan Raya Umum 1963}

Sarawak United People's Party (SUPP), pelopor parti politik di Sarawak telah didaftarkan secara rasmi pada 12 Jun 1959.58 Ibu pejabat SUPP terletak di Kuching yang menjadi pusat gerakan utama parti ini. SUPP 
diketuai oleh Ong Kee Hui dengan Stephen Yong sebagai Setiausaha. Penubuhan SUPP dibenarkan oleh Gabenor Sarawak sebagai sebuah parti berbilang kaum tetapi parti ini telah dimonopoli oleh orang Cina. Untuk memperluaskan pengaruhnya, SUPP telah menubuhkan cawangan dan ranting parti di seluruh Sarawak. Cawangan dan ranting ini berfungsi menyampaikan maklumat dan arahan dari ibu pejabat parti di Kuching dan mengambil ahli-ahli baru. Pada tahun 1961, SUPP mendakwa telah mempunyai lebih 45,000 ahli dengan 46 cawangan dan ranting yang dibentuk di seluruh Sarawak..$^{59}$

SUPP mendapat sokongan yang kuat di Sarawak khasnya dari kalangan orang Cina. Keadaan ini membimbangkan pihak kerajaan dan pemimpin kaum lain tentang penguasaan SUPP dalam politik Sarawak nanti. Justeru itu, kerajaan menggalakkan penubuhan parti-parti politik lain di Sarawak untuk memecahbelahkan pengaruh SUPP. Berikutnya, orang Melayu menubuhkan Parti Negara Sarawak (PANAS) dan Barisan Rakyat Jati Sarawak (BARJASA). Orang Dayak membentuk Sarawak National Party (SNAP) dan Parti Pesaka Anak Sarawak (PESAKA). Dalam pada itu, pada tahun 1962, sebuah lagi parti Cina, Sarawak Chinese Association (SCA) ditubuhkan yang tidak sealiran dengan perjuangan SUPP. Dengan itu, penglibatan orang Cina dalam politik Sarawak diwakili oleh dua buah parti politik, iaitu SUPP dan SCA. Dengan itu juga, jelas bahawa penubuhan SUPP telah mendorong kaum Melayu dan Dayak untuk menubuhkan parti politik mereka bagi memelihara kepentingan kaum masing-masing.

Semasa gagasan Malaysia diumumkan, SUPP bertindak membantah cadangan Tunku Abdul Rahman itu yang melibatkan percantuman Tanah Melayu, Singapura, Brunei, Sarawak dan Borneo Utara sebagai satu unit politik. SUPP menganggap gagasan Malaysia akan merugikan mereka kerana pemerintahan kerajaan di Tanah Melayu didominasi oleh orang Melayu. Ini bermakna SUPP bimbang bahawa Sarawak akan dikuasai oleh Tanah Melayu. Dalam pada itu, SUPP berpendapat Sarawak harus diberi kemerdekaan sepenuhnya sebelum mempertimbangkan penyatuan dengan unit politik yang lain..$^{60}$ Malahan selepas Sarawak mencapai kemerdekaan melalui Malaysia pada 16 September 1963, SUPP masih menjadi parti pembangkang.

Selain SUPP, penglibatan orang Cina dalam gerakan politik di Sarawak juga dapat dilihat melalui penubuhan SCA. SCA ialah parti politik Cina kedua yang ditubuhkan di Sarawak. Ini berikutan dengan kesedaran dalam kalangan golongan Cina berharta bahawa komuniti Cina memerlukan sebuah organisasi politik yang dapat memelihara kepentingan mereka apabila Sarawak mencapai kemerdekaan. Golongan ini merasakan bahawa SUPP yang tidak menyokong penubuhan Malaysia itu sudah tentu akan dikecualikan dalam kerajaan 
apabila Sarawak merdeka kelak. SCA didaftarkan pada Julai 1962. Pengasasnya terdiri daripada ahli perniagaan Cina, iaitu komuniti Teochew dari Kuching dan komuniti Foochow dari Sibu. SCA dianggap oleh orang Cina sebagai parti pro-kerajaan yang disokong oleh golongan kaya dan berpengaruh.

Penubuhan SCA bukan sahaja untuk menyatukan orang Cina menjadi rakyat yang setia kepada negeri Sarawak tetapi juga agar dapat merapatkan hubungan mereka dengan kaum Bumiputera dalam proses Sarawak ke arah berkerajaan sendiri. ${ }^{61}$ Jawatankuasa Pusat pertama SCA di bawah pimpinan William Tan dianggotai oleh majoriti orang Cina Teochew dari Kuching. Walau bagaimanapun, menjelang pilihan raya tahun 1963, Jawatankuasa Pusat SCA diambil alih oleh suku Foochow dari Bahagian Ketiga di bawah pimpinan Ling Beng Siew. Ini kerana menjelang pilihan raya, perasaan tidak puas hati wujud dalam anggota parti berhubung dengan kekurangan persediaan dan pembiayaan bagi kempen SCA dalam pilihan raya itu. Akibatnya, komposisi Jawatankuasa Pusat berubah dan dalam proses itulah William Tan dilantik sebagai penasihat manakala Ling Beng Siew sebagai Pengerusi SCA. ${ }^{.2}$

Berbeza dengan SUPP, SCA menyokong rancangan Malaysia yang dicadangkan oleh Tunku Abdul Rahman. SCA bersetuju dengan rancangan Malaysia kerana parti ini yakin Sarawak akan menikmati kemerdekaan dan pemerintahan sendiri melalui pembentukan Malaysia. SCA percaya sebagai sebahagian daripada kawasan Asia Tenggara dan terletak berdekatan dengan pusat politik dunia, Sarawak senang ditakluki oleh kuasa lain. Oleh itu, sekiranya negeri Sarawak cuba berdiri sendiri pasti akan gagal. Dengan itu, SCA menyokong penyertaan Sarawak dalam Persekutuan Malaysia untuk mendapatkan kerajaan sendiri dan kemerdekaan. ${ }^{63}$

Menjelang proses ke arah pembentukan Persekutuan Malaysia telah wujud kesedaran dalam kalangan pemimpin-pemimpin parti politik pro-Malaysia untuk bersatu di bawah satu perikatan agar dapat menewaskan SUPP dalam pilihan raya tahun 1963. Atas kesedaran ini, SCA dan empat parti politik pro-Malaysia (PANAS, SNAP, PESAKA dan BARJASA) telah membentuk satu pakatan yang dikenali Sarawak Allinince Party (SAP). ${ }^{64}$ SAP bertujuan menyatukan penduduk negeri Sarawak dan mencapai kemerdekaan bagi Sarawak dalam lingkungan Malaysia. lni selaras dengan objektif dan perjuangan SCA. Maka, tidak hairanlah SCA menyertai SAP bersama-sama dengan parti komponen lain untuk bersaing dengan SUPP dalam pilihan raya tahun 1963.

Pilihan raya 1963 menjadi medan penentu kejayaan SCA untuk menggugat kepimpinan SUPP dalam kalangan masyarakat Cina. Namun demikian, keputusan pilihan raya menunjukkan SCA gagal 
menjadi parti dominan dalam kalangan orang Cina. Sebaliknya, SUPP terus mendapat sokongan utama daripada masyarakat Cina. Daripada jumlah 429 kerusi Majlis Daerah yang ditandingi, akhirnya SCA hanya memenangi lima kerusi (termasuk dua kerusi calon bebas yang menyertainya selepas pilihan raya) manakala SUPP mendapat 116 kerusi. Secara keseluruhannya, sejumlah 138 kerusi dikuasai oleh SAP termasuk lima kerusi dari SCA, 59 dimenangi oleh PANAS dan 116 kerusi oleh calon bebas. ${ }^{65}$ Sementara itu, perwakilan SUPP dalam Majlis Undangan Negeri ialah lima orang dan SCA hanya tiga orang sahaja. Manakala, SAP mendapat sejumlah 26 kerusi (termasuk tiga kerusi dari SCA). ${ }^{66}$ Dengan itu, jelas bahawa SUPP masih lebih digemari oleh penduduk Cina di Sarawak berbanding dengan SCA.

Walau bagaimanapun, berdasarkan keputusan pilihan raya tersebut, SUPP tidak layak membentuk kerajaan di Sarawak. Sebaliknya, SAP yang disertai oleh SCA, BARIASA, SNAP dan PESAKA yang mendapat kemenangan besar dalam pilihan raya adalah layak untuk mentadbir dan berkuasa di Sarawak. Dengan itu, kerajaan pertama Sarawak di bawah pimpinan orang Sarawak sendiri telah dibentuk dengan Stephen Kalong Ningkan (dari SNAP) sebagai Ketua Menteri yang pertama. ${ }^{67}$ Namun demikian, dalam perkembangan tersebut, orang Cina telah memainkan peranan penting dalam menggerakkan penubuhan parti politik dan seterusnya pergabungan parti-parti politik pro-Malaysia menjelang kemerdekaan.

\section{Kesimpulan}

Jelas orang Cina yang berasal daripada golongan imigran itu kemudiannya telah berjaya menjadi satu golongan yang penting dalam perkembangan politik di Sarawak. Orang Cina telah tiba di Sarawak pada pertengahan abad ke-19 dan mereka terlibat dalam pelbagai kegiatan ekonomi dari perlombongan, penanaman, pembalakan dan peniagaan sehingga kepada perusahaan. Pada peringkat awal kedatangan orang Cina ke Sarawak, mereka tidak berminat terhadap politik tempatan, sebaliknya mereka lebih berminat terhadap kekayaan dan peluang ekonomi. Bagaimanapun, mereka telah mula melibatkan diri dalam kegiatan sosial dan berpersatuan untuk menyatukan dan mencapai kerjasama serta memelihara kepentingan komunitinya di Sarawak.

Perubahan dalam masyarakat Cina mula dilihat apabila kerajaan memperkenalkan proses pilihan raya di Sarawak bermula dengan pilihan raya tempatan (KMC dan SUDC) pada tahun 1956 dan 1957. Orang Cina telah sedar bahawa penglibatan mereka dalam politik Sarawak adalah penting dan perlu memandangkan Sarawak dalam 
persediaan ke arah berkerajaan sendiri dan kemerdekaan. Berikutnya, parti politik, SUPP ditubuhkan oleh orang Cina dan seterusnya SCA dibentuk apabila gagasan Malaysia diumumkan oleh Tunku Abdul Rahman. Kedua-dua parti politik itu mewakili masyarakat Cina dalam pilihan raya umum Sarawak pada tahun 1963.

Penubuhan SUPP turut menggerakkan politik Sarawak ke satu tahap perkembangan yang lebih matang dengan munculnya partiparti politik yang memperjuangkan kepentingan orang Melayu dan Dayak, iaitu PANAS, SNAP, BARIASA dan PESAKA. Kesemua parti politik di Sarawak kecuali SUPP akhirnya mencapai kesepakatan untuk membentuk parti perikatan dan berjaya membentuk kerajaan Sarawak yang pertama selepas penubuhan Malaysia. Berdasarkan perkembangan tersebut, tidak dapat dinafikan orang Cina pada asalnya adalah imigran yang datang untuk mencari peluang ekonomi, akhirnya telah bergiat aktif dalam gerakan politik dan menjadi penggerak politik berparti di Sarawak.

\section{Nota}

1 Y.L. Lee, "The Chinese in Sarawak and Brunei", Sarawak Museum Journal, Vol. XI, No. 23-24, 1964, hlm. 518; Michael B. Leigh, The Chinese Conmutuity of Sarawak, Singapore: University of Singapore, 1964, hlm. 29; Lee Yong Leng, Penduduk dan Petempatan di Sarawak, Kuala Lumpur: Dewan Bahasa dan Pustaka, 1981, hlm. 130; James Jackson, Suruceak: Satu Kajian llmu Alan tentang sebuah negeri yantg sedang mentbangun, Kuala Lumpur: Dewan Bahasa dan Pustaka, 1976, hlm. 52.

2 Graham Saunders,"The Bau Chinese Attack On Kuching, February 1857: A Different Perspective", Sarauak Museum Journal, Vol. XLII, 1991, hlm. 378-380; Craig A. Lockard, "The 1857 Chinese Rebellion in Sarawak: A Reappraisal", ISEAS, Vol. IX, No. 1, March 1978, hlm. 85-98; Craig A. Lockard, Chinese Sociely and Politics in Sarawak: Historicul Essays, Sibu, Sarawak: Sarawak Chinese Cultural Association, 2009, hlm. 158-163; Craig A. Lockard, Chinese Immigration and Society in Sarawak 1868-1917, Sibu, Sarawak: Sarawak Chinese Cultural Association, 2003, hlm. 10-11; Joan Lo, Glimpses From Saratuak's Past, Kuching, Sarawak: Agas (s) Sdn. Bhd., 1986, hlm. 134-147; Tom Harrisson, "Gold and Indian Influences in West Borneo", Malayan Branch Royal Asiatic Society, Vol. XXII, Part IV, September 1949, hlm. 50-51. Lihat juga Radio Times of Sarailak, Programmes from 22 September to 5 October 1957, Vol. 3, No. 20, hlm. 26-27; Programmes from 6 October to 19 October 1957, Vol. 3, No. 21, hlm. 29; The Sararak Gazette, 30 November 1964, hlm. 291.

3 Ho Hui Ling, 'Politik Orang Cina di Sarawak, 1941-1963', Disertasi Sarjana, Jabatan Sejarah, Fakulti Sastera dan Sains Sosial, Universiti Malaya, Kuala Lumpur, 1998, hlm. 27.

4 Joan Lo, Glimpses From Sarawak's Past, hlm. 153. 
5 S. Baring-Gould and C. A. Bampfylde, A History of Sarawak Under Its Two Rajahs 1839-1908, London: Henry Southerson \& Co., 1909, hlm. 32-33.

- Ooi Keat Gin, Of Free Trade and Native Interests: The Brookes and The Economic Development of Sarawak, 1841-1941, Kuala Lumpur: Oxford University Press, 1997, him. 33.

7 Craig A. Lockard, Chinese Socicty and Politics in Sarazak, hlm. 22-29; Craig A. Lockard, Clinese Immigration and Society in Sararoak 1868-1917, hlm. 46-58. Lihat juga Joan Lo, Glimpses From Saranak's Past, hlm. 154-156.

8 Craig A. Lockard, Chinese Immigration and Society in Sarawak 1868-1917, hIm. 23-27.

9. The Saratuak Gazette, 1 December 1925, hIm. 322.

10 Sarawak Administrative Report, Kuching, 1931, hlm. 26.

11 Daniel Chew, Chinese Pioneers on the Sarawak Frontier 1841-1941, Singapore: Oxford University Press, 1990, hlm. 23 dan 40; Lee Yong Leng, Penduduk dan Petempatan di Sarawak, hIm. 128-129; James Jackson, Sarawak, hlm. 52-53.

12 Ooi Keat Gin, "Chinese Vernakular Education in Sarawak during Brooke Rule, 1841-1946", Modern Asian Studies, Vol. 28, Pt. 3 (July 1994), hlm. 516; Craig A. Lockard, "The South East Asian Town in Historical Perpective: A Social History of Kuching, 1820-1970', Ph.D. Thesis, University of Wisconsin. 1973, hlm. 376; John M. Chin, The Sarawak Chinese, Kuala Lumpur: Oxford University Press, 1981, hlm. 88.

13 John M. Chin, The Sarawak Chinese, hlm. 73, 80-84; Craig A. Lockard, "Leadership and Power within the Chinese Community of Sarawak", ISEAS, Vol. 11, No. 2, September 1971, hlm. 199-200; The Sarawak Government Gazette, 29 June 1946, hIm. 78-79.

14 The Sarawak Gazette, 1 September 1888, hlm. 109-110. Lihat juga The Sarawak Gazette, 1 August 1894, hlm. 118.

15 The Sarawak Government Gazette, 1 July 1930, hlm. 242; 2 January 1932, hlm. 33. Lihat juga Daniel Chew, Chinese Pioneers on the Sarazak Frontier 1841-1941, hlm. 176

16 The Sarawak Gonemiment Gazette, 2 January 1932, hIm. 34. Lihat juga Daniel Chew, Chinese Pioneers on the Sarawak Frontier 1841-1941, hlm. 176; Diu Mee Kuok, 'The Diffusion of Foochow Settlement in the Sibu-Binatang, Central Sarawak, 1901-1970', M.A. Thesis, University of Hawaii, 1972, hIm. 60 .

17 The Sarawak Government Gazette, 1 July 1930, hlm. 241 dan 243; 2 January 1932, hlm. 34

18 R.H.W. Reece, The Name of Brooke: The End of White Rajah Rule in Sarawak, Kuala Lumpur: Ox ford University Press, 1982, hlm. 141.

19 Yoji Akashi, "Japanese Policy Towards The Malayan Chinese 1941-1945", JSEAS, Vol. 1, No. 2, September 1970, hlm. 67-68.

20 R.H.W. Reece, The Name of Brooke, hlm. 156; R.H.W. Reece, 'The Cession of Sarawak to the British Crown in 1946', Ph.D. Thesis, Australian National University, Canberra, 1977, hlm. 218; Lee Kam Hing \& Chow Mun Seong, 
Biograplical Dictionary of the Chinese in Malaysia, Petaling Jaya: Pelanduk Publications, 1997, hlm. 57.

21 The Sarmoak Tribune, 15 August 1946, hlm. 6.

22 Sarawak Annual Report 1947, Kuching: Government Printing Office, 1948, hlm. 2; Syed Idrus Syed Ahmad \& R. Santhiram, Perkembangan Pendidikan di Sarawak, Kuala Lumpur: Dewan Bahasa dan Pustaka, 1990, hlm. 116; R.H.W. Reece, The Name of Brooke, hlm. 148.

23 A.V.M. Horton, "Japanese Occupation", Jemal Persatuan Sejarah Malaysia (Canangan Sarawak), Disember 1976, hlm. 13.

24 R.H.W. Reece, The Name of Brooke, hlm. 141 dan 145; Footprints In Saraunk, Menoirs of Tan Sri Datuk(Dr) Ong Kee Hui 1914 to 1963, Kuching: Research \& Resource Centre, SUPP Headquaters, 1998, hlm. 214.

25 R.H.W. Reece, The Name of Brooke, hlm. 153.

20. Ibid., hlm. 158; Haji Mohammad Hasbie Sulaiman, Perjuangan Anti-Cession Sarawak: Peranan Utama Persatuan Kebangsaan Melayu Sarawak, Kuching: Persatuan Kebangsaan Melayu Sarawak, 1989, hlm. 43-44.

27 Radio Times of Sarawak, Programmes from 19 May to 1 June 1957, Vol. 3. No. 11, hlm. 30; Programmes from 27 July to 9 August 1958, Vol. 4, No. 16, hlm. 33; The Saratoak Gazette, 1 February 1947, hlm. 22.

28 R.H.W. Reece, The Name of Brooke, hlm. 159; R.H.W. Reece, "The Cession of Sarawak to the British Crown in 1946', hlm. 218.

$2^{4} \quad$ R.H.W. Reece, The Name of Brooke, hlm. 159; Haji Mohammad Hasbie Sulaiman, Perjuangam Anti-Cession Saratuk, hlm. 44-45. Lihat juga Chung Wha Joumal, 27 January 1950, hlm. 4.

30 Bagi Kuching dan Binatang, lihat The Sarawak Government Gazette, 1 June 1946, hlm. 38; untuk Bau, lihat The Sarawak Government Gazette, 16 May 1946, hlm. 17; untuk Batu 10 Penrissen Road, lihat The Sarawak Government Gazette, 17 June 1946, hlm. 54 dan bagi Batu Kawa, lihat The Sarawak Government Gazette, 1 October 1946, hlm. 114.

31 The Sarawak Government Gazette, 1 June 1946, hlm. 38.

32 The Saraziak Gozernment Gazette, 1 June 1946, hlm. 37; 16 December 1949, hlm. 609. Rujuk juga Kho Chong Soo (ed.), The British Borneo Year Book, Vol. 1, Singapore: Mun Ngai Press \& Co., 1952, hlm. 35 dan 68.

33 The Sararoak Tribnne, 28 A pril 1947, hlm. 1; 9 August 1947, hlm. 1; 20 January 1948, hlm. 2; 9 March 1948, hlm. 1; 7 January 1949, hlm. 2. Lihat juga John M. Chin, The Surawak Chinese, hlm. 112-113; Michael Beckett Leigh. "The Development of Political Organization and Leadership in Sarawak, East Malaysia', Ph.D. Thesis, Cornell University, 1971, hlm. 11.

34 Ho Hui Ling, "Penyerahan Sarawak kepada Kerajaan British, 1946-1951", Malaysin dari segi Sejarah, Bil. 29, 2001, hlm. 44-48; Bujang Bin Mohammed Nor, The Cession of Sarazuk To Great Britain 1946, Kuching, Sarawak: Rassnorm Sdn. Bhd., 1999, hIm. 16-26.

35 The Sarantak Gazette, 7 December 1949, hlm. 313-315; The Saratuak Tribune, 12 December 1949, hIm. 2; Llusan Saratuak, 12 December 1949, hIm. 4; 13 December 1949, hlm. 4; The Sarawak Government Gatztte, 16 December 1949, hIm. 609. Lihat juga Sanib Said, 'Anti-Cession Movement 1946 to 1951: The Birth of Nasionalism in Sarawak', B.A. Thesis, University Malaya, Kuala 
Lumpur, 1975, hlm. 32-59; Sanib Said, Malay Politics in Sarawak 1946-1966: The Search for Unity and Political Ascendancy, Singapore: Oxford University Press, 1985, hlm. 56.

36. Clung Wha Joumal, 3 April 1950, hlm. 1.

37 The Sarawak Tribune, 27 February 1961, him. 5.

38 The Sarawak Gazette, 2 September 1946, hlm. 16.

39 The Sarawak Tribune, 15 February 1946, hlm. 2.

40 The Sarazuak Tribune, 6 May 1946, hlm. 1; See Hua Daily Nezos, 22 October 1996, hlm. 8. Lihat juga Haji Mohammad Hasbie Sulaiman, Perjuangan Anti-Cession Sarazok, hlm. 74.

41 The Sarazak Tribune, 15 February 1946, hlm. 2; 16 February 1946, hlm. 3.

42 R.H.W. Reece, 'The Cession of Sarawak to the British Crown in 1946', hlm. 357.

43 Ho Hui Ling, "Penyerahan Sarawak kepada Kerajaan British, 1946-1951", hlm. 64-65.

44 Maklumat lanjut, lihat Ho Hui Ling, "Kegiatan Calndestine Communist Organisation (CCO) di Sarawak, 1950-1963: Satu Tinjau an Umum", Sejarah, Jurnal Jabatan Sejarah Universiti Malaya, No. 7, 1999, hlm. 183-205.

45 Chin Ung-Ho, Chinese Politics in Sarawak: A Study of the Saratuk United People's Party, Kuala Lumpur: Oxford University Press, 1996, hlm. 40; Craig A. Lockard, From Kampung To City: A Social History of Kuching Malaysia 1820-1970, Athens: Ohio University, 1987, hlm. 168-169.

46 Richard C. Thornton, China: A Political History 1917-1980, Colorado: Westview Press/Boulder, 1973, hlm. 231-233; Lionel Max Chassin, The Communist Conquest of Clina, Cambridge: Harvard University Press, 1965 , hIm. 238-244.

47 B. Simandjuntak, Federalisme Tanah Melayn 1945-1963, Petaling Jaya: Fajar Bakti Sdn. Bhd., 1985, hlm. 141; Michael B. Leigh, The Chinese Community of Sarawak, hlm. 50; Vernon L. Porritt, British Colonial Rule in Sarawak, 1946-1963, Kuala Lumpur: Oxford University Press, 1997, hlm. 77; Mohd. Reduan Haji Asli, Pemberontakan Bersenjata Komunis di Malaysia, Kuala Lumpur: Dewan Bahasa dan Pustaka, 1993, hlm. 74-75. Lihat juga North Bomeo Nezos and Sabah Times, 15 Mac 1963, hlm. 2.

48 Sarawak By The Week, 10 March-16 March 1963, hlm. 1-3. Lihat juga Vernon L. Porritt, The Rise and Fall of Communism in Sarawak 1940-1990, Victoria, Australia: Monash University Press, 2004, hlm. 17-19; Ahmad Nidzammuddin Sulaiman et-al, Politik Sarcrwak, Kuala Lumpur: Dewan Bahasa dan Pustaka, 1994, hlm. 172. Rujuk juga C.O. 947/32, Paper for the Information of the Malaysia Commission, 1960-1962, hlm. 38-40; North Borneo News and Sabah Times, 15 March 1963, hlm. 2.

49 Vernon L. Porritt, British Colonial Rule in Sarawak, 1946-1963, hlm. 80; Vernon L. Porritt, The Rise and Fall of Communism in Sarawak 1940-1990, hlm. 10-11. Lihat juga The Sarawak Tribune, 30 October 1951, hlm. 1; 1 December 1951, hlm. 1; 14 February 1952, hlm. 1; The Sarawak Gazette, 31 December 1952, hlm. 276. 
50 John M. Chin, The Sarawak Chinese. hlm. 107-109; Vernon L. Porritt. The Rise and Fall of Communism in Sarawak 1940-1990, hlm. 8-9; Saroniak By The Week, 26 November-2 December 1961, hlm. 2.

s, Chin Ung-Ho, Chinese Politics in Sarawak, hlm. 44; John M. Chin, The Sarawak Clinese, hlm. 107-109.

52. Utusan Saratak, 18 August 1960, hlm. 1.

53 The Borneo Bulletin, 26 September 1959, hlm. 8-9.

54 Daily Express, 4 July 1963, hlm. 7.

${ }_{55}$ David Teng Lung Chi \& Daniel Ngieng Kiong Ann, The Challenges - SUPP in Focus, Sarawak: Think Management Consultants and Services Sdn. Bhd., 1990, hlm. 2. Lihat juga Joseph Camilleri, Southeast Asia In China's Foreign Policy, Singapore: Institue of Southeast Asian, 1975, hlm. 26; Chin Ung-Ho, Clinese Politics in Saraatak, hlm. 53.

5. Utusan Sarawak, 5 December 1956, hlm. 1.

57. Ltusan Sarauak, 7 January 1960, hlm. 3.

58 The Sarawak Tribune, 19 June 1959, hlm. 1; Pedoman Raayat, July 1959, hlm. 1; Nanyang Siang Pan, 27 August 1996, hIm. A8. Lihat juga Micheal B. Leigh, The Rising Moon: Political Change in Sarawa, Sydney: Sydney University Press, 1974, hlm. 8-21; Craig A. Lockard, "Parties, Personalities and Crisis

Politics in Sarawak", JSEAH, Vol. 8, No. 1, March 1967, hlm. 114. Lihat juga C.O. 947/35, Written Representations Kuching (English Language), hIm. 33.

59 Sarawnk By The Week, 26 November-2 December 1961, hlm. 4; The Borneo Bulletin, 9 December 1961, hlm. 2.

60 The Sarmoak Tribune, 31 May 1961, hlm. 1; The Borneo Bulletin, 3 June 1961, hlm. 1; 9 June 1962, hlm. 2; Nanyang Siang Pan, 27 August 1996, hlm. A8; The Vanguard, 11 July 1971, hlm. 1.

(1) The Sarawak Tribune, 27 June 1962, hlm. 1; 2 August 1962, hlm. 1; 12 February 1963, hlm. 6. Rujuk juga Nanyang Siang Pan, 27 August 1996, hlm. A8; The Sarawak Gazette, December 1992, hlm. 10. Lihat juga Michael B. Leigh, The Rising Moon, hlm. 22; Michael B. Leigh, The Chinese Community of Sarawak, hlm. 46-47; Chin Ung-Ho, Chinese Politics in Sarauak, hlm. 61.

62 The Sarawak Tribune, 2 August 1962, hlm. 1.

n. The Sarnakak Tribune, 12 February 1963, hlm. 6. Lihat juga Sarazoak By The Week, 10 February-16 February 1963, hIm. 14.

o4 Utusan Saranak, 1 December 1962, hlm. 1. Rujuk juga Sarawak By The Week, 13 January-19 January 1963, hlm. 1; 3 February-9 February 1963, hlm. 1.

65. Margaret Clark Roff, The Politics of Belonging: Political Change in Sabah and Sarawak, Kuala Lumpur: Oxford University Press, 1974, hlm. 123.

6h Michael B. Leigh, The Rising Moon, hlm. 95.

(6) Tan Sri Datuk Amar (Dr.) Ong Kee Hui, Footsteps in Malaysia: Political Development of Sarawak since 1963, Kuching, Sarawak: Research \& Resource Centre, SUPP Headquarters, 2002, hIm. 1-10. 